\title{
Utilization of Building Debris as Aggregates in Stone Columns
}

\author{
K.W.D. Sanjeewa and Udeni P. Nawagamuwa
}

\begin{abstract}
Due to rapid development and population growth, construction industry has emerged with few recent problems. The major problem faced by the construction industry is the scarcity of construction materials associated with environmental concerns on consuming virgin materials such as rock and soil. In addition to this, disposal of construction waste because of high disposal cost and inadequate land fill area has become a grave concern. Due to the remnants of 30year civil war happened in Sri Lanka, a huge amount of building debris is to be disposed during new infrastructure construction on the war affected areas mostly on soft and compressible soils. To reduce the amount of dumping these building debris, the possibility of using them (concrete, brick and plaster) in lieu of traditional rock aggregates as material to be used in stone column construction was studied in this research. Slake durability index and uniaxial compressive strength tests were carried out on selected building debris to find out the suitability of using them in stone columns. Improvement in shear strength of the soft soil was tested using Vane shear in radially as well as with depth in several laboratory models with a centrally located stone column made up of different building debris. It was observed that the model with concrete aggregates exhibited a similar capacity of traditional rock aggregates of same size.
\end{abstract}

Keywords: Building Debris, Waste Disposal, Stone Columns, Aggregates

\section{Introduction}

Due to rapid growth of population and infrastructure developments in Sri Lanka, construction industry has become very dynamic. The problems anticipated by the Government of Sri Lanka are scarcity of construction material and disposal of construction and demolition waste because of unavailability of land fill area to be used as dumping sites.

Most of the new roads have been designed through paddy fields, marshy lands, barren lands etc. to reduce disturbances to the present livelihood. Therefore, deep deposits of soft soils coupled with construction of high embankments could result in potentially large post construction settlements, which may exceed the post construction settlement limits. Therefore, in the long term (operational stage), Soft Ground Treatment (SGT) is required to control embankment settlement and stability whilst ensuring and maintaining an adequate pavement and structural performance during service life [15].

Where soft cohesive soil thickness is greater than $5 \mathrm{~m}$ and stability and stringent post construction settlement requirements cannot be fulfilled using conventional ground treatment methods such as remove/replace, preloading and preloading with wick drains, ground improvement techniques involving vibrodisplacement can be positively considered. Columns formed using the vibro displacement method is often referred to as stone columns [10]. Construction of stone columns consumes a huge quantity of different materials, and, the major consumption of materials is stone or rock aggregates. However, recently encountered problem in acquiring sufficient road construction material (especially aggregates) for road projects is due to natural geological reasons as well as protests after environmental awareness among the public. In addition to that, disposal of huge quantities of building debris and other construction wastes is also a grave concern to the authorities because of limited landfill area and huge cost of transportation [16]. Sri Lanka is practicing open dumping at lowlands in most of the waste dumping situations, nevertheless, disposing of industrial waste in these lands will cause flooding, environmental degradation and could affect the livelihood of residents.

Hence, it is regarded as one of the best solutions to reuse the construction waste and building debris in construction projects.

Eng. K.W.D. Sanjeewa, B.Sc.Eng.Hons (Moratuwa), M.Eng. (Moratuwa), AMIE (Sri Lanka),

Project Engineer - Central Expressway Project 03/RDA

Email:sanjeewadilan01@gmail.com

(D) ORCID ID: $h$ ttp://orcid.org/0000-0002-0165-2794

Eng.(Dr.) Udeni P. Nawagamuwa, B.Sc.Eng.Hons (Moratuwa), M.Eng. (AIT), Dr.Eng. (YNU), C.Eng., FIE

(Sri Lanka), Senior Lecturer, Department of Civil

Engineering, University of Moratuwa, Sri Lanka.

Email:udeni@civil.mrt.ac.lk

D ORCID ID: http://orcid.org/0000-0002-3472-6622 


\section{Stone Column Construction}

Among the various techniques for improving in situ ground conditions, reinforcing the ground with stone columns or granular piles is one of the most versatile and cost-effective methods. Load bearing columns of well compacted coarse aggregates are installed in the ground to serve various purposes such as reinforcement, densification and drainage [9]. Stone columns provide the primary functions of reinforcement and drainage by improving the strength and deformation properties of the soft soil [10]. Therefore, advantages of stone columns can be such as; increase the bearing capacity of in-situ soils,

reduce total and differential settlements, expedite consolidation settlement and mitigate the risk of liquefaction. Stone columns are most effective in clayey soils with undrained shear strength in the range 7-50 kPa [Indian Standard (IS) 15284; Bureau of Indian standards (BIS), 2003] [24]. The most common material used for stone column construction is crushed stone aggregates, size varying in the range $12-100 \mathrm{~mm}$ [11], [12]. Due to high angle of internal friction and stiffness of stone columns when compared to that of in-situ weak soil, majority of applied load is transferred to stone columns. As a result, lesser load is transferred to surrounding weak soil. This leads to reduction in settlement [8].

The use of stone columns is best suited for ground conditions where soft cohesive soil thickness is greater than $5 \mathrm{~m}$ and where stability or stringent post construction settlement requirements cannot be fulfilled using conventional ground treatment methods such as removal/replacement, preloading and preloading with wick drains. Stone columns can be applicable for soft, non-compactible, weak soil, granular soil with high fines content, organic soils, marine/alluvial clays, liquefiable soils and cohesive soils [4].

The stone columns derive their load carrying capacity from the lateral earth pressure/radial confining stress against bulging from surrounding soil [3]. However, when stone columns are installed in extremely soft soils having undrained shear strength less than 7 $\mathrm{kPa}$, the radial confinement/restraint offered by the surrounding soil is inadequate, resulting in excessive lateral displacement of stone into the surrounding soil. In such circumstances, the load carrying capacity of the stone column can be improved by encasing the column in a suitable geosynthetic. The length of stone columns over which bulging takes place is known as critical length (about 4 times the diameter of the column). Apart from the bulging, stone columns derive their load carrying capacity through surface resistance or frictional resistance developed between the column material and surrounding weak soil acting upwards within the critical length, and also from the passive resistance mobilized by the column material. The portion of the stone column below the critical length does not contribute to load transfer but functions similar to a vertical drain and accelerates the consolidation of the surrounding soft soil [3].

Natural rock aggregates are the basic materials used in stone column construction. Whatever installation techniques used, engineering properties and behavior of stone column construction materials (aggregates) will vary considerably [7]. As such, the testing of these materials is essential to ensure the quality and durability of the stone columns constructed. It must be noted that the construction of stone columns consumes a huge quantity of varied materials, and the major consumption of materials is stone or rock aggregates [19]. Due to problems in acquiring sufficient road construction aggregates, special attention must be drawn to use of alternative material to replace stone aggregate, either fully or partially, for the construction of stone columns with required parameters and performance [18]. Although there has been a lot of studies to improve stone column performance by encasing them or by inserting steel rebars, there has been only few studies carried out on the use of alternative materials to replace stone aggregate, either fully or partially, for the construction of stone columns.

\subsection{Use of Alternative Material for Stone Column Construction}

Sivakumar and Glynn (2004) [6] carried out experimental studies by considering four recycled waste materials such as freshly quarried basalt (for comparison purpose), quarry waste, building debris and crushed concrete and these materials were examined under various test conditions; namely, dry, wet and mixed with $10 \%$ and $20 \%$ clay slurry. Tests were also carried out to examine how the performance of these recycled waste materials could be enhanced using geogrids. Laboratory tests were carried out in a $305 \mathrm{~mm} \times 305 \mathrm{~mm}$ direct shear box. The results showed the 
performance of the recycled materials were not significantly different to that of freshly quarried basalt, although the conditions under which the products were tested (i.e. dry, wet and smeared with clay slurry) appeared to influence their performance in a significant way. A case study by [13] was reported in which spent railway track ballast and crushed concrete were used as aggregate for stone columns in the UK. Persichetti (2010) [17] has carried out a similar study with crushed concrete to check whether that could be used as a sustainable alternative to quarried crushed stone in vibro stone columns and used crushed concrete generated from the onsite demolition of a large slab and concrete columns. The allowable bearing pressure observed at foundations had been $6 \mathrm{ksf}$ or 290 $\mathrm{kPa}$ (column loads over 2,000 kips or $900 \mathrm{kN}$ ) and the settlement tolerance had been 1 inch $(25.4 \mathrm{~mm})$ total and 0.5 inch $(12.7 \mathrm{~mm})$ differential.

Ramanathan and Sasikala (2014) [5] had carried out experimental studies to measure the behavior of single stone columns made of both tyre chips and stone aggregates. Fifteen model experiments had been carried out on stone columns made of different mix proportions of stone aggregate (S) and tyre chips (T), in a kaolinite clay bed of uniform consistency. They found that the mixtures of $60 \% \mathrm{~T}+40 \% \mathrm{~S}$ and $40 \% \mathrm{~T}+60 \% \mathrm{~S}$ provided a load-carrying capacity in stone columns similar to that of stone columns made using stone aggregate $(100 \% \mathrm{~S})$. This concludes that waste tyre chips could be used as a partial replacement for stone aggregate up to about $40-60 \%$ in the construction of stone columns. Siddhartha, Parbin and Ashim (2016)[20] had carried out experimental and analytical studies for use of Jhama columns as replacement of stone columns and a good agreement of experimental and analytical results was observed.

Having gone through the literature, the purpose of this study is considered as to identify suitable building debris and to utilize them as aggregate in stone columns for improving unsuitable ground in road construction projects. This would reduce the construction cost as well as help overcome the problem of disposal of building debris. Concrete, plaster and block masonry units comprising burnt brick pieces were identified as mostly available and were selected to investigate the suitability as aggregates in stone columns for road construction work.

\section{Characterization of Materials}

\subsection{Clay}

A clay found in the proposed Central expressway project region was collected in the study. According to the Unified Soil Classification System (USCS) based on particle size distribution and the plasticity characteristics of the clay, it is classified as a High Plasticity Silt (MH) [23].

According to the American Association of State Highways and Technical Official (AASHTO) soil classification, this soil sample belongs to A7-5 group and it is classified as Very Poor Clayey Soil [21].

Activity of the clay (A) was 0.36 which is less than 0.75 and therefore it is considered as Inactive Soil [Skempton (1953)] [2]. Basic properties of the clay are presented in Table 1.

Table 1 - Properties of the Clay Sample

\begin{tabular}{|l|l|}
\hline \multicolumn{1}{|c|}{ Property } & \multicolumn{1}{c|}{ Value } \\
\hline Specific Gravity & 2.57 \\
\hline Liquid Limit: \% & 70 \\
\hline Plastic Limit: \% & 51.2 \\
\hline Plasticity Index: \% & 18.8 \\
\hline Maximum Dry Density: kg/m ${ }^{3}$ & 1590 \\
\hline Optimum Moisture Content: \% & 21.7 \\
\hline Clay: \% (<0.002 mm) & 52.3 \\
\hline Silt: \% $(0.002-0.075 \mathrm{~mm})$ & 38.4 \\
\hline Sand: \% (>0.075 mm) & 9.3 \\
\hline Organic Matter (content): \% & 12 \\
\hline Coefficient of Permeability: $\mathrm{m} / \mathrm{s}$ & $2.5 \mathrm{E}-10$ \\
\hline
\end{tabular}

\subsection{Building Debris used in the Model Studies}

Aggregates for the model tests were selected from among the building debris as the particles passing through a $14 \mathrm{~mm}$ sieve and retained on a $10 \mathrm{~mm}$ sieve as proposed by [12] and [14].The debris consists of concrete, plaster and block masonry.

\subsection{Stone Aggregates}

To compare the behaviour of building debris with that of stone aggregate, the size of the stone aggregate was maintained exactly similar to that of the building debris. Crushed stone aggregates passing through a $14 \mathrm{~mm}$ sieve and retained on a $10 \mathrm{~mm}$ sieve were chosen for the study. 


\section{Methodology}

This research is an experimental study to investigate the suitability of engineering properties of various kinds of building debris for Stone Column Construction. Samples of plaster, concrete and block masonry were collected and ASTM standard tests mentioned in Table 2 were carried out for each sample separately and stone columns made with them [22].

Table 2 - Standard Tests

\begin{tabular}{|l|l|}
\hline \multicolumn{1}{|c|}{ Tests } & \multicolumn{1}{c|}{ Tested Sample } \\
\hline $\begin{array}{l}\text { AIV,LAAV } \\
\text { and ACV } \\
\text { tests }\end{array}$ & $\begin{array}{l}\text { each debris sample } \\
\text { separately }\end{array}$ \\
\hline $\begin{array}{l}\text { Slake } \\
\text { durability } \\
\text { index test }\end{array}$ & $\begin{array}{l}\text { each debris sample } \\
\text { separately after one and two } \\
\text { months-soaked period to } \\
\text { evaluate water effect for } \\
\text { durability }\end{array}$ \\
\hline $\begin{array}{l}\text { Vane shear } \\
\text { test }\end{array}$ & $\begin{array}{l}\text { clay surrounding the stone } \\
\text { column model made of each } \\
\text { debris material separately }\end{array}$ \\
\hline $\begin{array}{l}\text { Uniaxial } \\
\text { compressive } \\
\text { strength test }\end{array}$ & $\begin{array}{l}\text { stone column model made of } \\
\text { each debris material } \\
\text { separately }\end{array}$ \\
\hline
\end{tabular}

\subsection{Test Set-up and Loading Arrangement} for Stone Column Model

An acrylic cylindrical tank $300 \mathrm{~mm}$ high was used as the model tank. The diameter of the tank was $200 \mathrm{~mm}$ with a wall thickness of $5 \mathrm{~mm}$. The scaling factor used for the stone column model was $1 / 12$ as proposed by [14] and [12]

The stone column diameter used for the test was $45 \mathrm{~mm}$. In the tank, clay was placed uniformly to a height of $225 \mathrm{~mm}$ and the stone column was installed at the centre. The height of the stone column was $225 \mathrm{~mm}$. This was chosen in such a way that the length (L) to diameter (d) ratio $(\mathrm{L} / \mathrm{d})$ was a minimum of 5 , which was required to develop the full limiting axial stress on the column [4].

The total height of the clay bed placed in the tank was five times the diameter of the column. The initial gap between the bottom of the stone column and the bottom of the tank base was $50 \mathrm{~mm}$. This gap was filled with sand at a density maintained at $1951 \mathrm{kgm}^{-3}$. Another sand layer of $20 \mathrm{~mm}$ thickness was placed on the top of the stone column, with a diameter equal to $100 \mathrm{~mm}$ to act as a sand pad. A vertical load was applied over a diameter equal to the circular influence area that is more than two times the diameter of the stone column. The load was applied through a proving ring at a constant strain rate of $0.25 \mathrm{~mm} / \mathrm{min}$. The typical loading arrangement used in the present study is shown in Figures 1(a) -1(b).
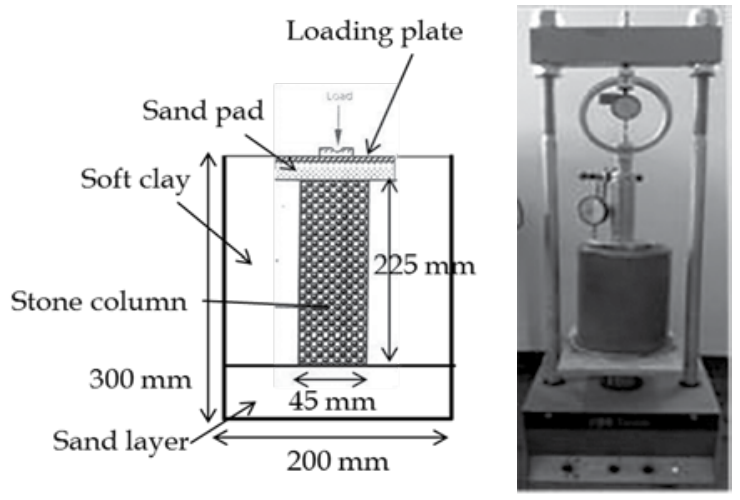
(a) Sketch
(b) Experimental Set-up

Figure 1 - Typical Loading Arrangement of a Stone Column

\subsection{Preparation of the Clay Bed}

Sufficient amount of clay was collected with minimum disturbance from a place where a highway construction is proposed. Shear strength of the clay varies with the water content, so it was necessary to conduct all the experiments with the same water content to compare the performance of the stone column. The clay was then covered with wet cloths until it was placed in the made PVC column. Silicon grease was applied to the PVC column wall to reduce any possible interface friction between the clay and the column wall. The test column was inserted into the clay sample in a basket to take column sample manually. Samples were spread and patted evenly to avoid entrapment of air. Care was taken to ensure that no air was entrapped within clayey soil as they were inserted into columns or between the soil and the column wall. The measurements of water content with different heights of the clay layer (top, middle and bottom) for each trial of model test was same, and proved that the clay bed was prepared homogeneously.

\subsection{Construction of the Stone Column Model}

The column was constructed by the replacement method. The centre of the cylindrical tank was accurately marked. A $45 \mathrm{~mm}$ outer diameter, thin, open-ended and seamless polyvinyl chloride (PVC) pipe was pushed into the clay up to $225 \mathrm{~mm}$ at the middle of area. A thin coat of grease (less than $1 \mathrm{~mm}$ thick) was applied both the inner and outer surfaces of the pipe for easy withdrawal 
without any disturbance to the surrounding soil. A small helical auger was used for scooping out the soil within the casing PVC pipe. Selected building debris samples of 10-14 $\mathrm{mm}$ in size were charged into the hole in layers of $30 \mathrm{~mm}$, giving a light uniform compaction to each layer. The casing pipe was raised in stages, ensuring a minimum of $5 \mathrm{~mm}$ penetration below the gravel placed. This process was carried out in each set up. It was also observed that, after removing the casing pipe, the grease coat remained on the pipe only. Hence, this grease coat did not affect the smearing and hydraulic conductivity of the interface between the stone column and the surrounding soil. Finally, stone column of the building debris within clay surrounding was made.

Having prepared the stone column up to the soil level, sand passing through a $4.75 \mathrm{~mm}$ sieve was placed as a blanket of a $20 \mathrm{~mm}$ thickness over the prepared stone column. Finally, a loading cap $100 \mathrm{~mm}$ in diameter, which is equal to the diameter of the circular influence area and $12 \mathrm{~mm}$ thick, was placed over the stone column to apply the load evenly at the centre. The load deformation behaviour of the column was studied by loading it in a loading machine frame at a strain rate of $0.25 \mathrm{~mm} / \mathrm{min}$. The load was observed for equal intervals of $0.125 \mathrm{~mm}$ displacement. Since the loading was rapid, it was essentially undrained loading which simulates loading immediately after construction.

\section{Results}

\subsection{Results of Building Debris Tests}

5.1.1 Aggregate Impact Value, Aggregate Crushing Value, Los Angeles Abrasion Value Test Results

Aggregate Impact Value (AIV), Aggregate Crushing Value (ACV), Los Angeles Abrasion Value (LAAV) tests results for Aggregate, brick debris, concrete debris and cement plaster are shown in Tables 3-5.

Table 3 - Results of Aggregate Impact Value Test of Different Type of Debris

\begin{tabular}{|l|c|c|c|}
\hline \multicolumn{1}{|c|}{ Test No. } & $\mathbf{1}$ & $\mathbf{2}$ & AIV(\%) \\
\hline Concrete debris & $30.3 \%$ & $31.7 \%$ & $31 \%$ \\
\hline Aggregate & $24.6 \%$ & $25.4 \%$ & $25 \%$ \\
\hline Brick debris & \multicolumn{4}{|c|}{ unable to obtain a result } \\
\hline $\begin{array}{l}\text { Cement plaster } \\
\text { debris }\end{array}$ & \multicolumn{3}{|c|}{ unable to obtain a result } \\
\hline
\end{tabular}

Table 4 - Results of Aggregate Crushing Value Test of Different Types of Debris

\begin{tabular}{|l|c|c|c|}
\hline \multicolumn{1}{|c|}{ Test No. } & $\mathbf{1}$ & $\mathbf{2}$ & ACV(\%) \\
\hline Concrete debris & $35.1 \%$ & $34.9 \%$ & $35 \%$ \\
\hline Aggregate & $24.9 \%$ & $25.4 \%$ & $25 \%$ \\
\hline Brick debris & \multicolumn{3}{|c|}{ unable to obtain a result } \\
\hline $\begin{array}{l}\text { Cement plaster } \\
\text { debris }\end{array}$ & \multicolumn{3}{|c}{ unable to obtain a result } \\
\hline
\end{tabular}

Table 5 - Results of Los Angeles Abrasion Value Test of Different Types of Debris

\begin{tabular}{|l|c|c|c|}
\hline \multicolumn{1}{|c|}{ Test No. } & $\mathbf{1}$ & $\mathbf{2}$ & LAAV (\%) \\
\hline Concrete debris & $35.4 \%$ & $36.6 \%$ & $36 \%$ \\
\hline Aggregate & $31.9 \%$ & $30.9 \%$ & $31 \%$ \\
\hline Brick debris & \multicolumn{3}{|c|}{ unable to obtain a result } \\
\hline $\begin{array}{l}\text { Cement plaster } \\
\text { debris }\end{array}$ & \multicolumn{3}{|c}{ unable to obtain a result } \\
\hline
\end{tabular}

\subsubsection{Slake Durability Index Test Results}

Results of slake durability test for different types of building debris with respect to different soaked period are shown in Figure 2.

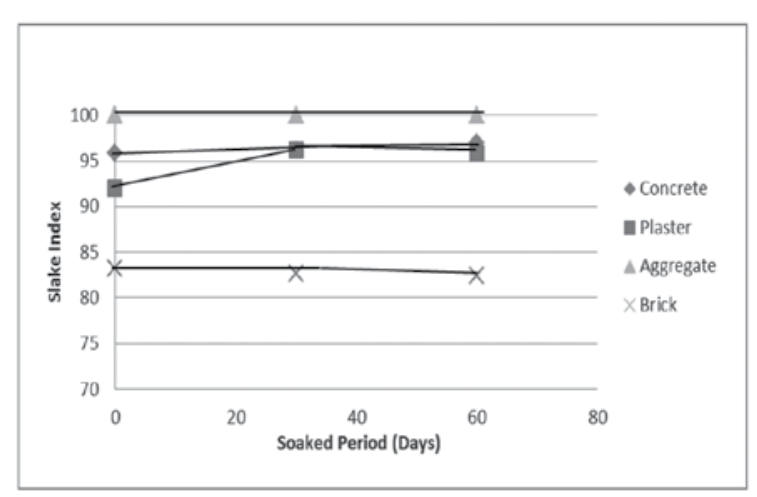

Figure 2 - Results of Slake Durability Tests for Different Types of Building Debris with Time

\subsection{Results of Stone Column Model Tests \\ 5.2.1 Compressive Strength Test Results}

Results of compressive strength test for different type of building debris can be shown in Figure 3. Here clay is used as a compare the unimproved ground. 


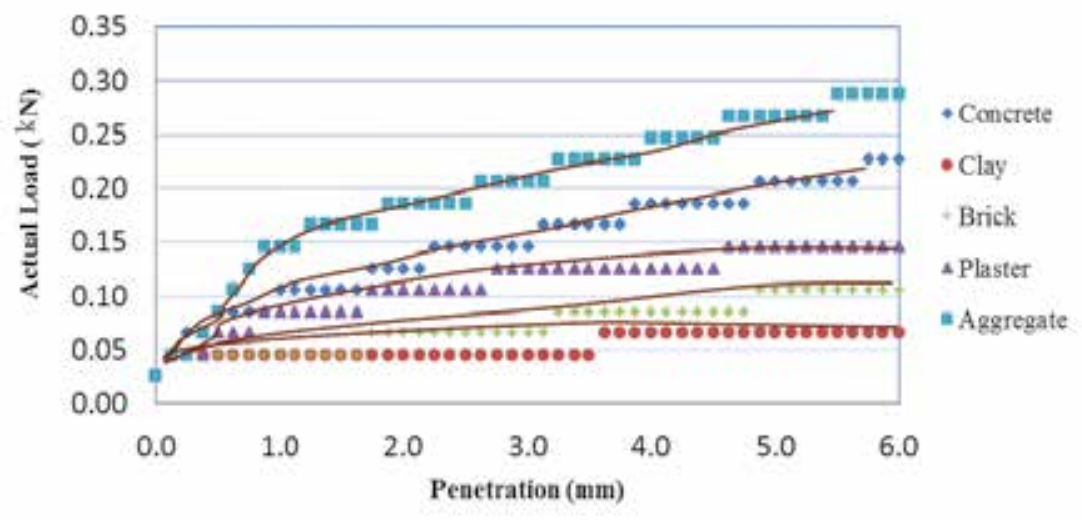

Figure 3 - Results of Compressive Load and Penetration for Different Types of Building Debris

\subsubsection{Vane Shear Test Results}

Results of Vane shear tests conducted at two distinct radial distances such as $80 \mathrm{~mm}$ and $35 \mathrm{~mm}$ from the centre of the stone column for different type of building debris are shown in Tables 6 and 7, respectively. Vane shear readings were taken at two different depths; at the surface and at a depth of $80 \mathrm{~mm}$ from the surface to measure the impact with the depth. Further, to evaluate the time effect all these measurements were done on the day, 7 and 30 days after the model preparation was completed.

Table 6 - Results of Vane Shear Test of Clay Sample at a Radial Distance of $80 \mathrm{~mm}$ from the Centre of Model

\begin{tabular}{|c|c|c|c|c|c|c|c|c|c|c|}
\hline Days & \multicolumn{6}{|c|}{$\begin{array}{c}\text { Shear Strength (kPa) at surface (just } \\
\text { below blade height -33 mm) in clay with } \\
\text { Made Stone Column }\end{array}$} & \multicolumn{3}{c|}{$\begin{array}{c}\text { Shear Strength (kPa) at 80 mm depth } \\
\text { from the surface in clay with Made Stone } \\
\text { Column }\end{array}$} \\
\cline { 2 - 13 } & Aggregate & Concrete & Plaster & Brick & $\begin{array}{c}\text { (Only } \\
\text { Clay) }\end{array}$ & Aggregate & Concrete & Plaster & Brick & $\begin{array}{c}\text { (Only } \\
\text { Clay) }\end{array}$ \\
\hline 0 & 6 & 6 & 6 & 5 & 2 & 7 & 7 & 6 & 6 & 3 \\
\hline 7 & 7 & 6 & 6 & 6 & 3 & 10 & 9 & 9 & 9 & 4 \\
\hline 30 & 8 & 7 & 7 & 7 & 4 & 12 & 10 & 10 & 10 & 5 \\
\hline
\end{tabular}

Table 7 - Results of Vane Shear Test of Clay Sample at a Radial Distance of $35 \mathrm{~mm}$ from the Centre of Model

\begin{tabular}{|c|c|c|c|c|c|c|c|c|c|c|}
\hline Days & \multicolumn{9}{|c|}{$\begin{array}{c}\text { Shear Strength (kPa) at surface (just } \\
\text { below blade height-33 mm) in clay with } \\
\text { Made Stone Column }\end{array}$} & \multicolumn{2}{c|}{$\begin{array}{c}\text { Shear Strength (kPa) at 80 mm depth from } \\
\text { the surface in clay with Made Stone } \\
\text { Column }\end{array}$} \\
\cline { 2 - 13 } & Aggregate & Concrete & Plaster & Brick & $\begin{array}{c}\text { (Only } \\
\text { Clay) }\end{array}$ & Aggregate & Concrete & Plaster & Brick & $\begin{array}{c}\text { (Only } \\
\text { Clay) }\end{array}$ \\
\hline 0 & 7 & 7 & 7 & 6.5 & 3 & 9 & 8 & 9 & 8 & 4 \\
\hline 7 & 9 & 9 & 8 & 9 & 4 & 11 & 11 & 10 & 11 & 6 \\
\hline 30 & 10 & 10 & 9 & 10 & 5 & 13 & 12 & 11 & 12 & 7 \\
\hline
\end{tabular}

\section{Analysis}

\subsection{AIV, ACV \& LAAV Tests}

Table 8 - Summary of AIV, ACV and LAAV Tests

\begin{tabular}{|l|c|c|c|}
\hline Sample & AIV & ACV & LAAV \\
\hline $\begin{array}{l}\text { Concrete } \\
\text { Debris }\end{array}$ & 31 & 35 & 36 \\
\hline Aggregates & 25 & 25 & 31 \\
\hline Brick & \multicolumn{4}{|c|}{ Unable to prepare a sample } \\
\hline Plaster & \multicolumn{4}{|c|}{ Unable to prepare a sample } \\
\hline
\end{tabular}

As per the ICTAD Publication for Standard Specifications for Construction and Maintenance of Roads and Bridges (SSCM) [25], stone column material should have following properties as shown in Table 9;

Table 9 - RDA Criteria for stone column material

\begin{tabular}{|l|l|}
\hline \multicolumn{1}{|c|}{ Test } & Properties \\
\hline AIV (\%) & $<30$ \\
\hline ACV (\%) & $<35$ \\
\hline LAAV (\%) & $<40$ \\
\hline
\end{tabular}




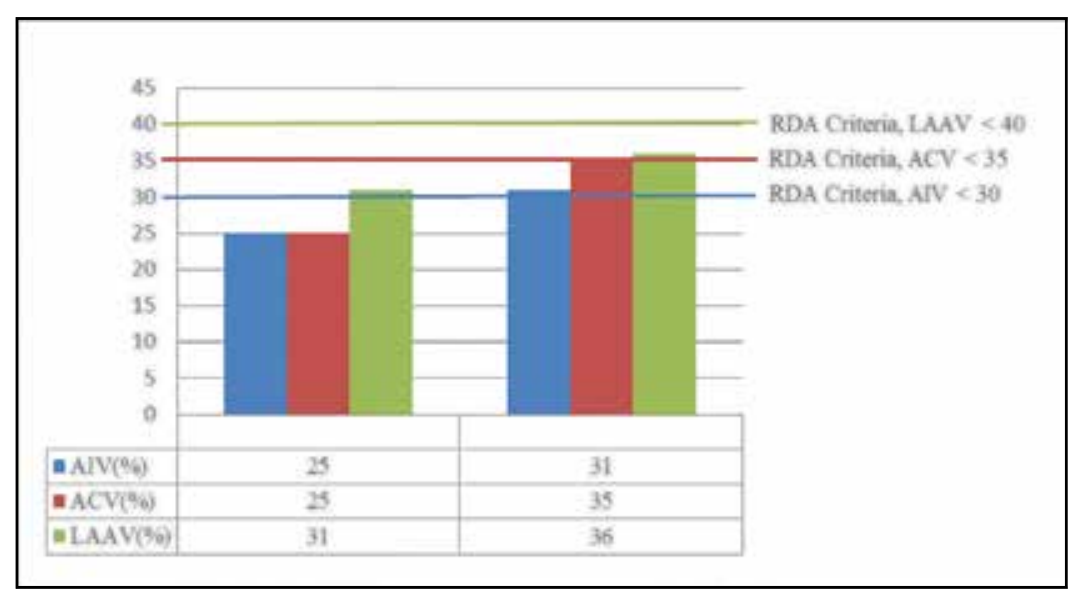

Figure 4 - Comparison of AIV, ACV and LAAV Tests

Considering RDA criteria given in Table 9 and Figure 4 for stone column material, aggregates can only be directly used for stone column construction. Only concrete debris, among other building debris fulfils the above requirements marginally. Therefore, concrete debris could be a feasible solution especially in situations where excessive concrete demolition waste is available.

\subsection{Slake Durability Test}

Using the results of slake durability test, slake durability index groups for different types of building debris can be analysed according to Gamble Classification [Goodman (1980)] [1]. Accordingly, slake durability index groups for different types of building debris are presented in Table 10.

Table 10 - Slake Durability Index Groups of Different Types of Debris

\begin{tabular}{|l|c|c|c|}
\hline \multirow{2}{*}{$\begin{array}{l}\text { Type of } \\
\text { waste } \\
\text { material }\end{array}$} & Initial & $\begin{array}{c}\text { Soaked for } \\
\text { one month }\end{array}$ & $\begin{array}{c}\text { Soaked } \\
\text { for two } \\
\text { months }\end{array}$ \\
\cline { 2 - 4 } Concrete & $\begin{array}{c}\text { Medium } \\
\text { High }\end{array}$ & $\begin{array}{c}\text { Medium } \\
\text { High }\end{array}$ & $\begin{array}{c}\text { Medium } \\
\text { High }\end{array}$ \\
\hline Plaster & Medium & $\begin{array}{c}\text { Medium } \\
\text { High }\end{array}$ & $\begin{array}{c}\text { Medium } \\
\text { High }\end{array}$ \\
\hline Brick & Low & Low & Low \\
\hline Rubble & Very High & Very High & Very High \\
\hline
\end{tabular}

It was clearly observed that the concrete is categorized as medium high durability in comparison to the other tested materials. This is still lower than the standard stone column fill material of rock aggregates. However, when aggregates' durability values are concerned, crushed concrete could be better utilized compared to other debris in stone column construction work instead rock aggregates subject to further testing.

\subsection{Compressive Strength Test}

According to the results of compressive strength test for different types of building debris, graphs shown in Figure 3 are plotted between compressive load and penetration. Subsequently the ultimate load for building debris was obtained.

Figure 3 clearly shows that the load-settlement behavior is non-linear for all materials tested. Aggregates have higher ultimate compressive load capacity $(250 \mathrm{~N})$ and, not surprisingly, it can be seen that the stone column made of only clay shows the lowest ultimate carrying capacity of $40 \mathrm{~N}$. Efficiency of building debris compared to rock aggregates can be tabulated as presented in Table 11.

Table 11 - Ultimate Load Efficiency of Building Debris Related to Aggregate.

\begin{tabular}{|l|c|c|}
\hline Description & $\begin{array}{c}\text { Ultimate } \\
\text { Load }\end{array}$ & $\begin{array}{c}\text { Percentage of } \\
\text { Efficiency } \\
\text { related to } \\
\text { Aggregate }\end{array}$ \\
\hline Aggregate & 250 & 100 \\
\hline Concrete & 180 & 72 \\
\hline Plaster & 120 & 48 \\
\hline Brick & 80 & 32 \\
\hline Clay & 40 & 16 \\
\hline
\end{tabular}

Accordingly, concrete has a higher efficiency in comparison with aggregate than other tested materials. For the same settlement, the 
difference in load-carrying capacity between the two materials is only marginal $(30 \mathrm{~N})$ at small settlements. However, it is significant $(80 \mathrm{~N})$ at high settlement, i.e. at the ultimate stage. A similar trend was observed for both trial tests conducted. Although there is a comparable difference between the stone columns made of aggregates and crushed concrete, concrete debris can be used as an aggregate for the construction of stone columns under working loads.

\subsection{Vane Shear Test}

It was found that the measured undrained shear strength in the model ranged from 5 to 13 $\mathrm{kN} / \mathrm{m}^{-2}$, thus proving the accuracy of the clay bed preparation work and stone column has been most effective in this type of clayey soils.

According to the results of shear strength of surrounding clay of these stone column models, it was observed that the shear strength has increased near stone column area compared to other distances. Thus, high shear strength can be observed at deeper levels of surrounding clay and strength decreases as depth becomes shallower. A chart of shear strength of stone columns made of different building debris surrounded by clay for a distance of $80 \mathrm{~mm}$ and $35 \mathrm{~mm}$ from the center is given in Figures 5 and 6 respectively.

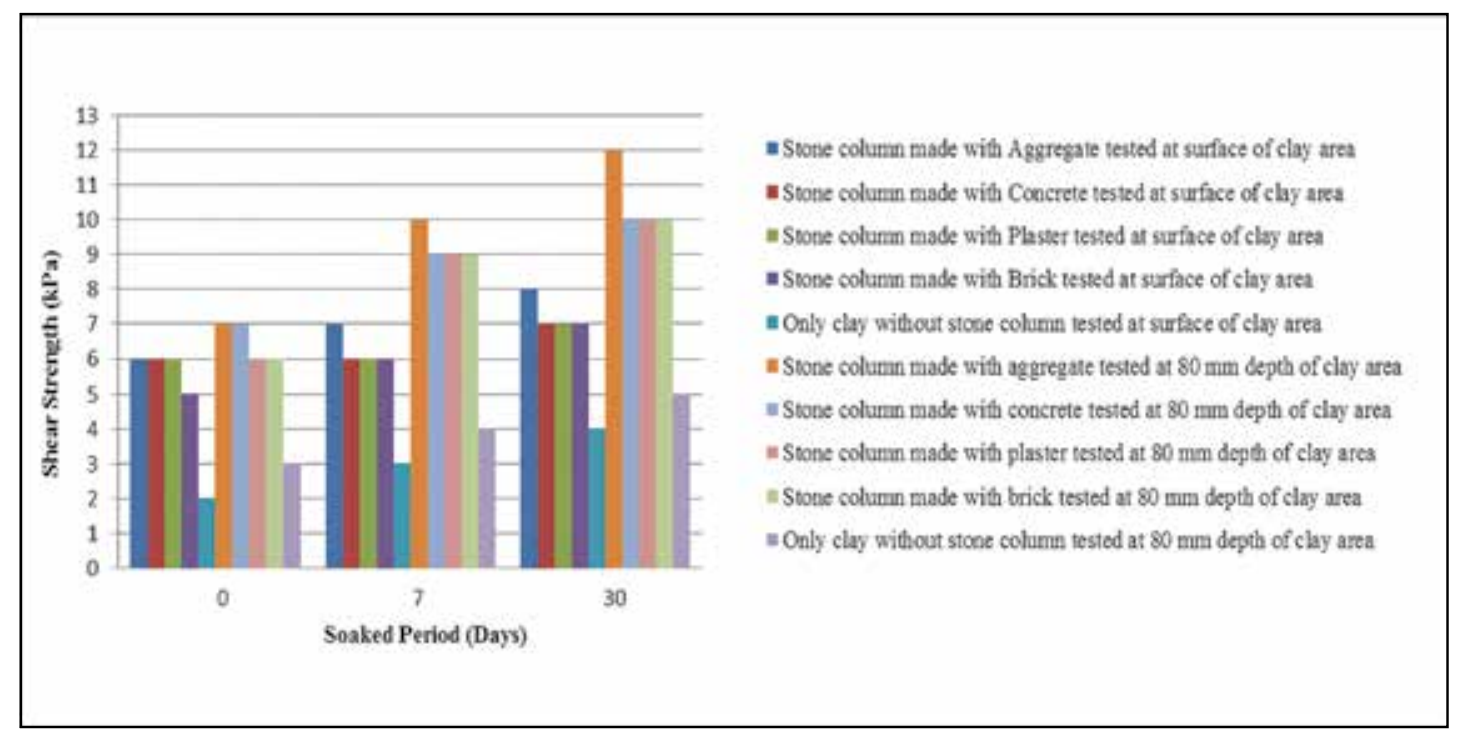

Figure 5 - Graphical Representation of Undrained Shear Strength in Clay Surrounding of Different Stone Column Models and Soaked Period Relationship at $80 \mathrm{~mm}$ Distance from the Centre of Stone Column

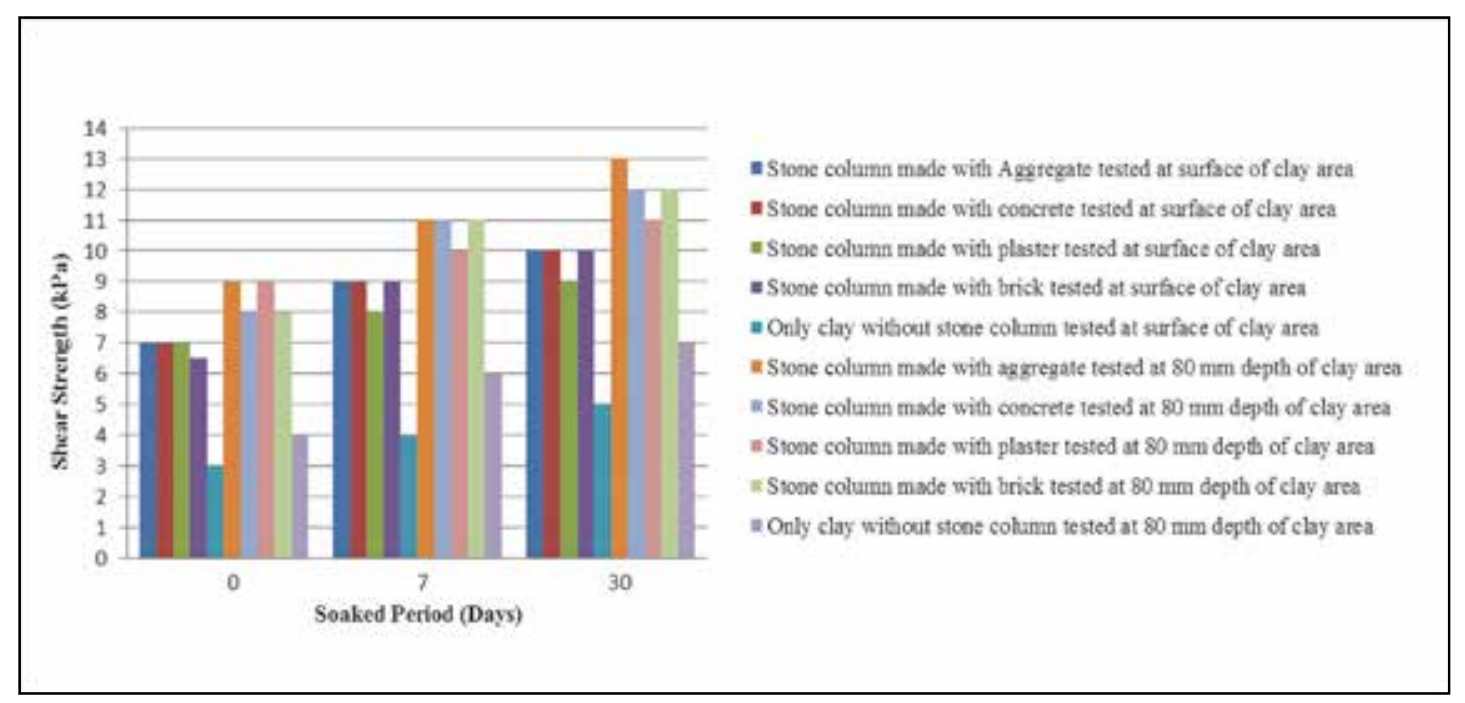

Figure 6 - Graphical Representation of Undrained Shear Strength in Clay Surrounding of Different Stone Column Models and Soaked Period Relationship at $35 \mathrm{~mm}$ Distance from the Centre of Stone Column 
Graphical representations of percentage of shear strength gain in clay surrounding the stone column made with different building debris compared to shear strength in clay without stone column Vs. time at same distance
(80 $\mathrm{mm}$ and $35 \mathrm{~mm}$ ) away from the centre of made stone column models but at different depths are given in Figures 7 and 8.

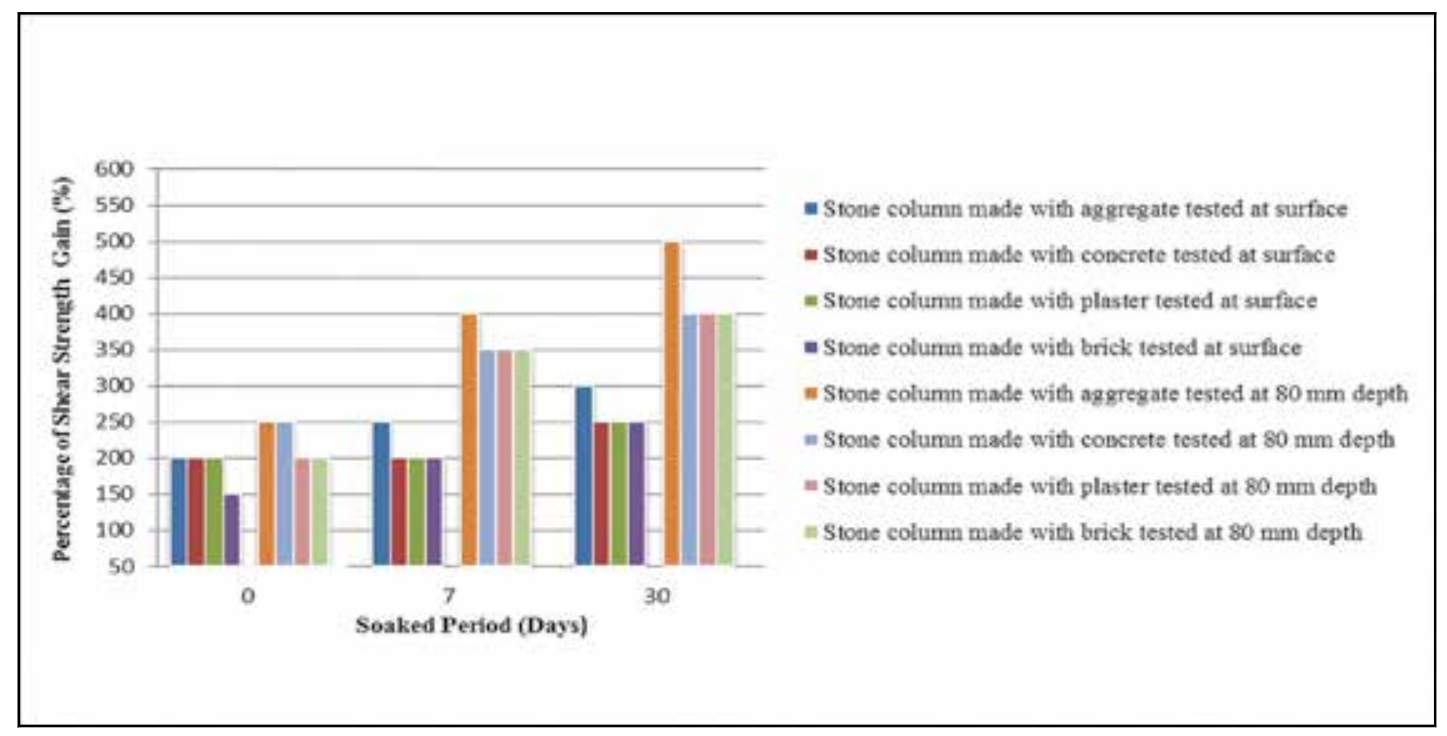

Figure 7 - Graphical Representation of Percentage of Shear Strength Gain in Clay Surrounding of Stone Column Models Made with Different Building Debris Compared to Shear Strength in Clay Without Stone Column Vs. Soaked Period at Same Distance $(80 \mathrm{~mm})$ from the Centre of Made Stone Column Models

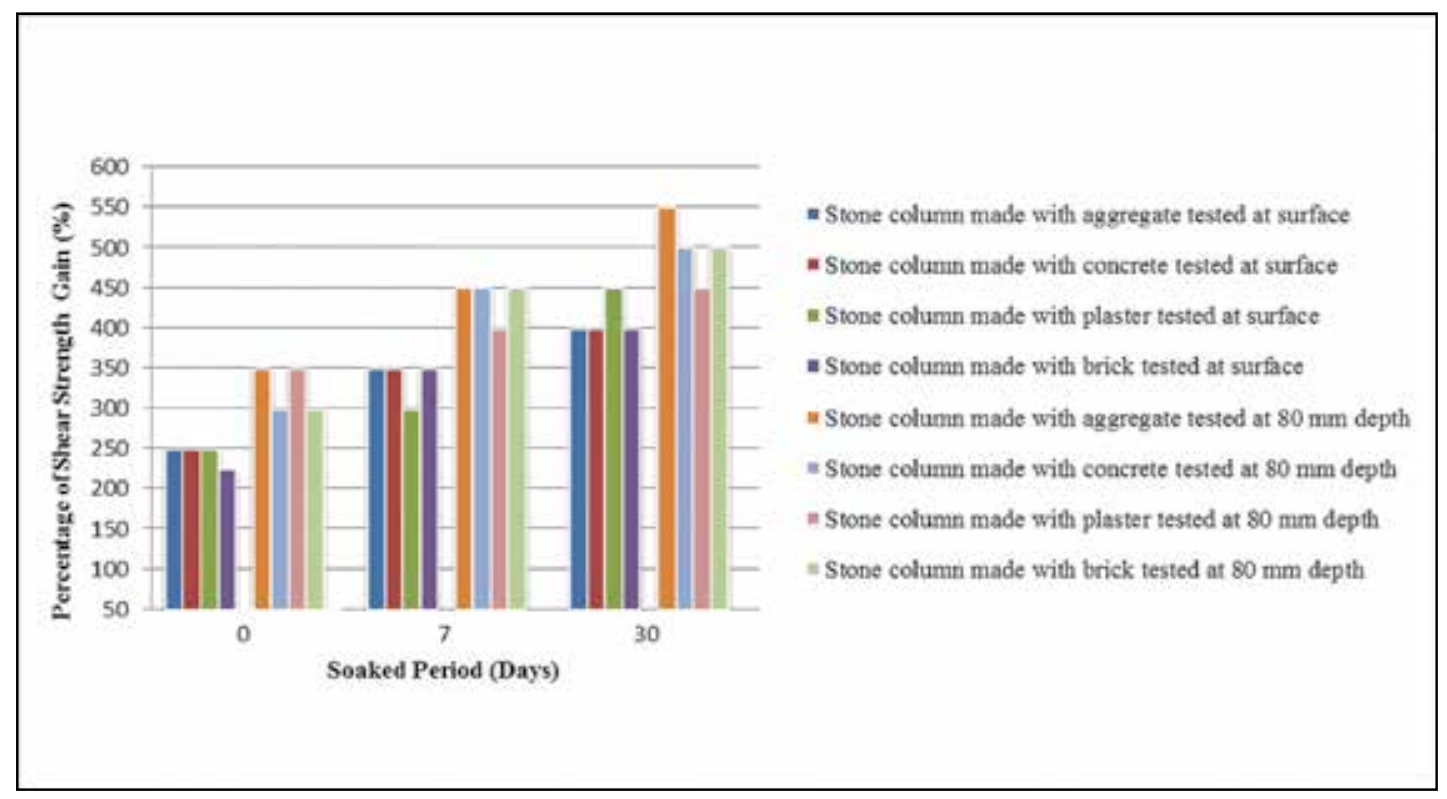

Figure 8 - Graphical Representation of Percentage of Shear Strength Gain in Clay Surrounding of Stone Column Models Made with Different Building Debris Compared to Shear Strength in Clay Without Stone Column Vs. Soaked Period at Same Distance (35 mm) from the Centre of Made Stone Column Models

Also, graphical representations of percentage of shear strength gain in clay surrounding columns made with different building debris compared to shear strength in clay without stone columns Vs. time at same tested depths
(33 $\mathrm{mm}$ and $80 \mathrm{~mm}$ without blade height) from the surface of made stone column models but different tested distances from the centre of made column models are given in Figures 9 and 10. 


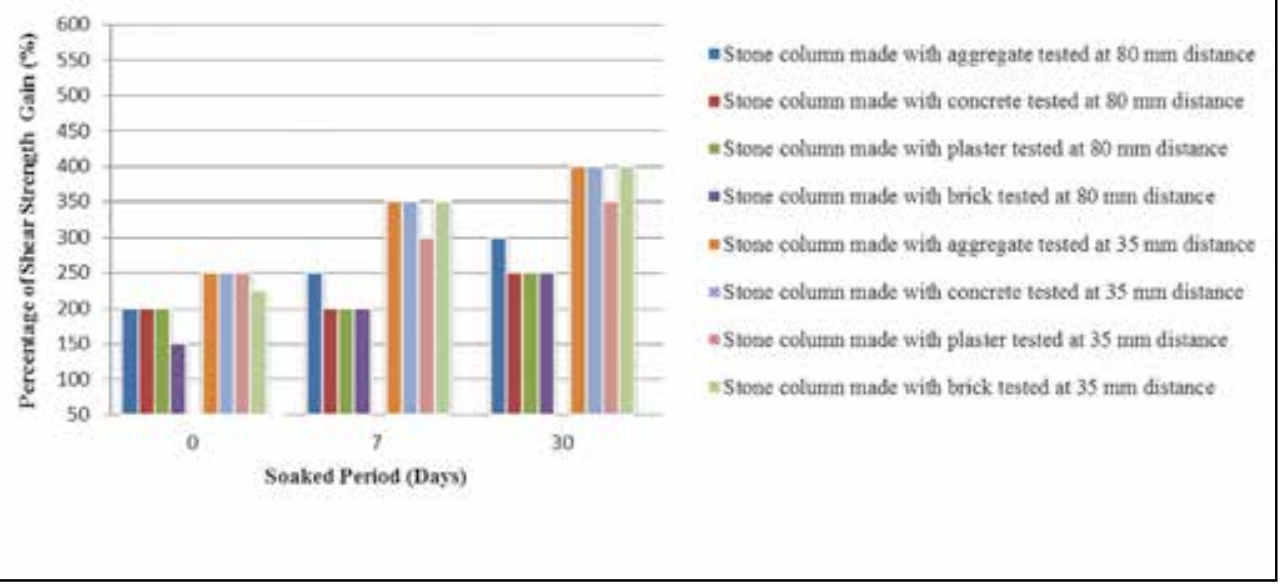

Figure 9 - Graphical Representation of Percentage of Shear Strength Gain in Clay Surrounding of Stone Column Models Made with Different Building Debris Compared to Shear Strength in Clay Without Stone Column Vs. Time at Same Depth Level $(33 \mathrm{~mm})$ from the Surface of Made Stone Column Models

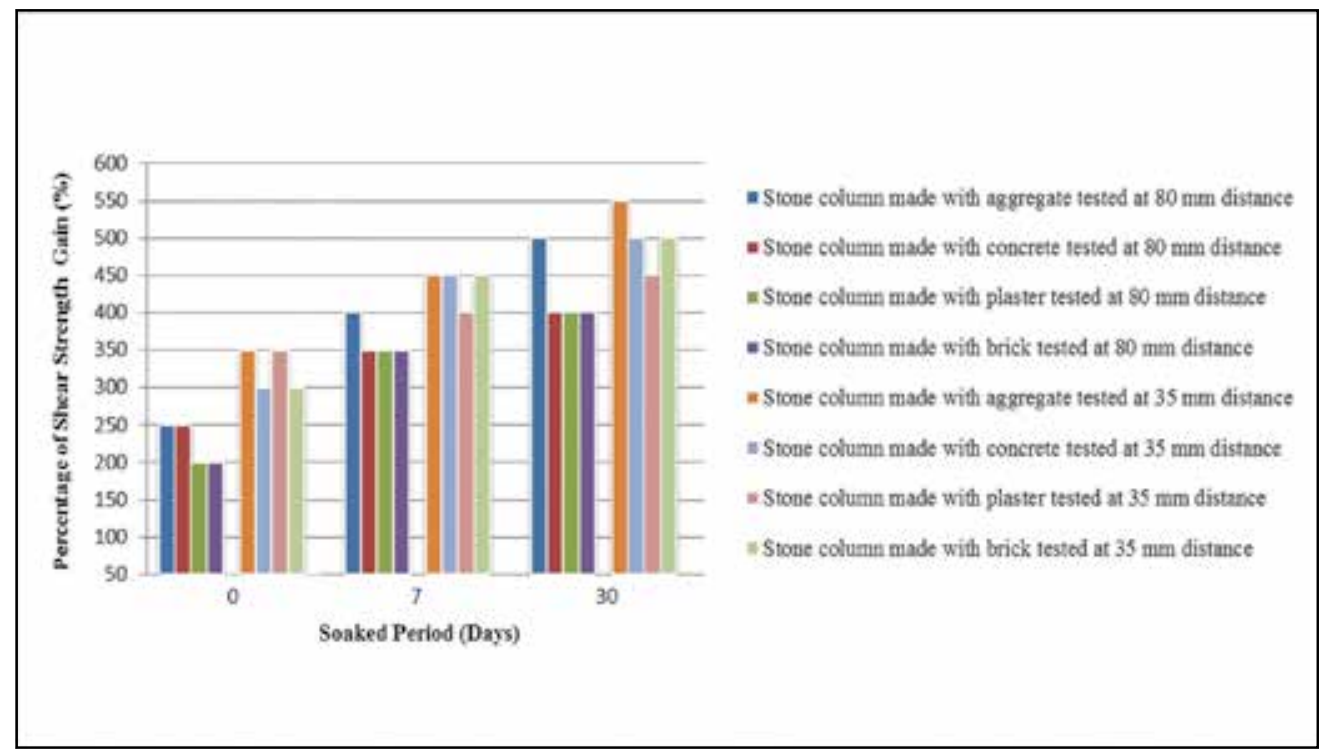

Figure 10 - Graphical Representation of Percentage of Shear Strength Gain in Clay Surrounding of Stone Column Models Made with Different Building Debris Compared to Shear Strength in Clay Without Stone Column Vs. Time at Same Depth Level $(80 \mathrm{~mm})$ from the Surface of Made Stone Column Models

Finally, it is observed that the undrained shear strength of clay without stone column is very low and it is clearly visible that the shear strength has increased more than 50\% of unimproved clay with stone column construction in clay area. Thus, shear strength at deeper levels and closer to a stone column with time has attained higher values than others because particles are much closer in that area due to horizontal and vertical load from made stone column. Also, shear strength of surrounding clay of made stone column models has improved with time because of acceleration of consolidation due to the presence of top and bottom drains of sand layers.

\section{Conclusion}

Stone columns improve the bearing capacity of soft clay soils by introducing a good drainage path and bearing the load through friction. The hardness and porosity of compacted stones make them ideal as granular column material. Since building debris (concrete, plaster and bricks) are not costly, easily available and possess comparable properties as stone, the utility of building debris as replacement of 
stone in granular columns was studied in this work.

Based on the requirements for aggregate material for stone column construction as per Standard Specification of Construction \& Maintenance (SSCM) of Roads \& Bridges and Gamble Durability Classification for durability of construction material, following conclusions were drawn from this study.

- Bricks are weak in durability and the compressive strength is very low $(0.08 \mathrm{kN}$ at $35 \mathrm{~mm}$ settlement). The shear strength is also low compared to aggregate strength, thus not suitable as a stone column fill material.

- Plaster shows medium durability and lowmedium compressive strength $(0.12 \mathrm{kN}$ at $35 \mathrm{~mm}$ settlement). The shear strength is medium compared to aggregate strength, thus cannot be used in high load bearing situations.

- Concrete shows medium high durability and high compressive strength $(0.18 \mathrm{kN}$ at $35 \mathrm{~mm}$ settlement) in comparison to the other tested materials. Still the compressive strength values were lower than the standard compressive strength value $(0.22 \mathrm{kN}$ at $35 \mathrm{~mm}$ settlement) of stone column fill material (i.e. aggregates). It was also clearly observed that model stone columns with aggregates and concrete particles separately, both provided relatively same results in shear strength at different distances and depths. Also concrete debris provided more than $70 \%$ of efficiency related to ultimate load carrying capacity of aggregate.

- Thus, shear strength of clay has improved with construction of stone column with concrete and increases with greater depth and closer to the stone column with time because of acceleration of consolidation due to the closeness of top and bottom drains of sand layers.

It was also clearly observed that model stone columns with aggregates and concrete particles separately, both provided relatively same results in shear strength, at different distances and depths and satisfied criteria for durability, $\mathrm{AIV}, \mathrm{ACV}$ \& LAAV and more than $70 \%$ of efficiency related to ultimate load carrying capacity of aggregate.

Therefore, it is proposed to utilize concrete particles in stone column construction in place of aggregates, especially in situations where excessive concrete demolition waste is available in Sri Lanka.
A reduction in the amount of stone aggregate used will lead to a reduction in the cost of stone columns as well as better utilization of waste material and protection of natural resources. Thus, use of particles of concrete debris has proved to offer a cost-effective and environmentally friendly technique.

\section{Acknowledgement}

Director General - RDA (Road Development Authority) and Project Director of Northern Expressway Project, RDA are acknowledged for providing support for this study. Staff members of RDA in Northern Province and Director Research and Development of RDA are also acknowledged. Also, the Staff members of the Soil Mechanics laboratory of the University of Moratuwa and the CEO of Engineering Consultants (Pvt) Ltd soil company for providing facilities for model tests are gratefully remembered.

\section{References}

1. Goodman, R.E., Introduction to Rock Mechanics, $2^{\text {nd }}$ ed., 1980, pp. 19-54.

2. Skempton, A., Activity of Clays on Soil Mechanics and Foundation Engineering, Switzerland, 3rd ed., August 1953, pp. 57-61.

3. Hughes, J. M. O. and Withers, N. J., "Reinforcing of Soft Cohesive Soils with Stone Columns, Ground Engineering", Vol. 7, No. 3, 1974, pp. 4249.

4. McKelvey, D., Sivakumar, V., Bell, A., and Graham, J., "Modeling Vibrated Stone Columns on Soft Clay", Geo-tech. Eng., 15(GE3), 2004, pp. 137-149.

5. Ramanathan, A., and Sasikala, S., "Model Tests on the Use of Tyre Chips as Aggregate in Stone Columns", The Institution of Civil Engineers, Ground Improvement 168, 2014, pp. 187-193.

6. Sivakumar, V. and Glynn, D., "Geotechnical Aspects of Recycled Construction Wastes", Queen's University of Belfast, United Kingdom, 2004, pp. 151-156.

7. Sivakumar, V., Mckinley, J. D. and Ferguson, D., "Reuse of Construction Waste: Performance under Repeated Loading", Geotechnical Engineering, 2002, Vo.157, No. 2, pp. 91-96.

8. Suriya, Pa., Praveen, S., Ponkarthi, J. and Nemalipuri K., "Performance of Clay Soil with Different Materials in Stone Column", Department of Civil Engineering, Aarupadai Veedu Institute of Technology, Chennai,India, 14(S1), 2016, pp. 348352. 
9. Ambily, A. P. and Gandhi, S. R., “Behavior of Stone Columns Based on Experimental and FEM Analysis", Journal of Geotechnical and Geo-environmental Engineering, ASCE 133(4): 2007, pp. 405-415.

10. Madhav, M. R., Murali, A. K. and Madhavi, L. G., "Densificaron Effect of Granular Piles on Settlement Response of Treated Ground", Journal of Ground Improvement, 11(3): January, 2007, pp. 127-136.

11. Mitchell, J. K. and Huber, T. R., (1985) "Performance of a Stone Column Foundation", Journal of Geotechnical and Geoenvironmental Engineering, ASCE 111(2): December, 2011, pp. 193-201.

12. Murugesan, S. and Rajagopal, K., (2007) "Model Tests on Geosynthetic-Encased Stone Columns", Journal of Geosynthetics International, 14(6): January, 2007, pp. 346354.

13. Serridge, C. J., (2005) "Achieving Sustainability in Vibro Stone Column Techniques", Journal of Engineering Sustainability, 158(4): January 2005, pp. 211222.

14. Wood, D. M., (2000) “Group Effects in Stone Column Foundations", Journal of Geotechnique, 50 (6): 2000, pp. 689-698.

15. Bryan, A. M., James, A. M. and Jonathan, A. B., "Ground Improvement using the VibroStone Column Technique", Joint meeting of Engineers Ireland West Region and the Geotechnical Society of Ireland, NUI Galway, 2007.

16. Chu, J., "Methods for Land Reclamation Using Soft Soil and Waste", NTU-JTC 13C Seminar, Nanyang Technological University, School of Civil and Environmental Engineering, August 2012.

17. Persichetti J., (2010) "Recycled Concrete as Vibro Stone Column Backfill", Sustainability Seminar, Hollywood, October 2010.

18. Imtiaz A., "Use of Waste Materials in Highway Construction", Final Report, Department of Civil Engineering, Purdue University, West Lafayette, Indiana 47907, 1991.

19. Isaac, D. S. and Girish, M. S., 'Suitability of Different Materials for Stone Column Construction", Department of Civil Engineering College of Engineering, Trivandrum, Kerala, 2009.
20. Siddhartha, K. K., Parbin, S. and Ashim, K.D., "Use of Jhama Columns as Replacement of Stone Columns", Indian Geotechnical Conference IGC2016, IIT Madras, Chennai, India, December 2016.

21. AASHTO M145-91 (American Association of State Highway and Transportation Officials): Standard Specifications for Classification of Soils and Soil-Aggregate Mixtures for Highway Construction Purposes, 2003.

22. ASTM (American Society for Testing and Materials): A.S.T.M D 4644-87, D2573 / D2573M -15 and D 2166 / D2166M - 16, D 854, D 4318, D 2216, D 421\&422, D 698-00a, D 2974 Standard Methods and Unified Soil Classification System (USCS) (ASTM D2487-11), ASTM International, West Conshohocken, PA,USA, 2004.

23. BS (British Standards): Methods of Test for soils for Civil Engineering Purposes. British Standards Institution, B.S 1377: Part 2, 1990, pp. 8-200.

24. IS (Indian Standards) 15284-1: Design and construction for ground improvement Guidelines, Part 1: Stone columns, Bureau of Indian Standards (BIS), 2003.

25. Standard Specification for Construction and Maintenance of Roads and Bridges, ICTAD SCA 5 , June 2009. 